\title{
SELENOP wt Allele
}

National Cancer Institute

\section{Source}

National Cancer Institute. SELENOP wt Allele. NCI Thesaurus. Code C105738.

Human SELENOP wild-type allele is located in the vicinity of $5 q 12$ and is approximately 88

$\mathrm{kb}$ in length. This allele, which encodes selenoprotein $\mathrm{P}$, plays a role in selenium

distribution. 